\title{
"Ruptured" malignant phyllodes tumor of the breast: a case report
}

This article was published in the following Dove Press journal:

International Medical Case Reports Journal

22 February 2016

Number of times this article has been viewed

\section{Chagkrit Ditsatham \\ Areewan Somwangprasert \\ Kirati Watcharachan \\ Phanchaporn \\ Wongmaneerung}

Division of Head, Neck and Breast, Department of Surgery, Chiang Mai University, Chiang Mai, Thailand
Correspondence: Chagkrit Ditsatham Department of Surgery, Faculty of Medicine, Chiang Mai University, I I0 Intavaroros Road,Amphoe Muang, Chiang Mai, Thailand 50200

Tel +6653945532

Fax +66 53946 I39

Email nansurg7@gmail.com
Abstract: Phyllodes tumor or cystosarcoma phyllodes is a rare disease and is usually seen in middle-aged patients. Ruptured phyllodes tumor is a very rare condition. Our study reports patient presentation, diagnosis method, and treatment of an unusual case. A 58-year-old premenopausal female was diagnosed with a phyllodes tumor and presented with a rapidly growing mass for 2 months that ruptured 1 month later. She underwent simple mastectomy at the left side of her breast and received adjuvant radiotherapy. No recurrence was found 4 months after operation.

Keywords: ruptured, malignant, phyllodes tumor, breast

\section{Introduction}

Phyllodes tumor or cystosarcoma phyllodes represents roughly $0.3 \%-0.9 \%$ of all breast tumors $^{1}$ and is usually seen in patients between $40-50$ years of age. ${ }^{2}$ World Health Organization has divided this tumor into three subtypes - benign, borderline, and malignant. Stromal elements of these tumors often form leaf-like projections lined by epithelium. Surgery remains the mainstay of the treatment in patients with phyllodes tumor and complete surgical resection offers high rates of local control. ${ }^{3}$

Ruptured phyllodes tumor is a very rare condition. Our study reports patient presentation, diagnosis method, and treatment of an unusual case admitted in the Division of Head, Neck and Breast, Chiang Mai University Hospital.

\section{Case presentation}

A 58-year-old premenopausal female with underlying diseases of Chiari I malformation with syringomyelia C1-T10 levels presented to the outpatient surgical unit in a Thai provincial hospital. She had a 2-month history of a mass in her left breast and eruption of the mass with pus through the skin for 1 month. The patient reported acceleration in the growth of the mass in the past month and also complained of occasional bleeding from the mass.

Physical examination revealed a huge mass that was ulcerated, having an irregular surface, occupying the entire left breast (Figure 1). The mass bled with surface contact. There was no axillary lymphadenopathy. The right breast was normal.

CT scan of the chest was performed which showed a large inhomogeneous enhancing mass at the left breast, measuring $13.4 \times 14.8 \times 14.3 \mathrm{~cm}$ in size with a round-shaped nodule in the posterior basal segment of the left lower lung, measuring $0.6 \mathrm{~cm}$ in size (Figure 2). The intra-abdominal organs were unremarkable. 


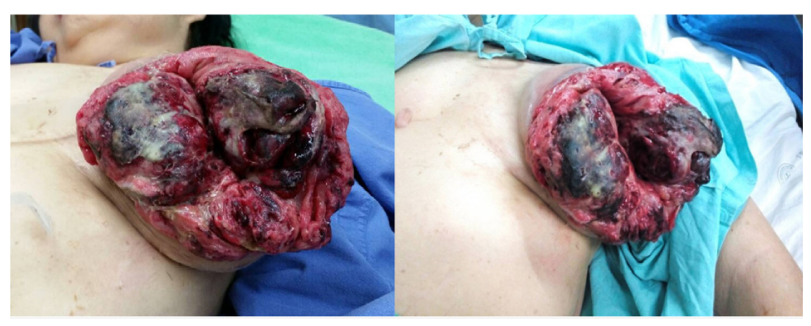

Figure I Tumor of entire left breast (rupture size $22 \times 18 \mathrm{~cm}$ )

Core needle biopsy indicated a fibroepithelial neoplasm and differential diagnosis included fibroadenoma or phyllodes tumor. The patient underwent a simple mastectomy under general anesthesia. The resected specimen was $22 \times 18 \mathrm{~cm}$ in size and the tumor did not invade the surrounding tissues. The specimen was sent for histopathology macroscopic examination as lobulated with focal necrosis and hemorrhage involving the entire specimen. The histopathology of the surgical specimen (Figure 3) revealed a malignant phyllodes tumor; 13 mitoses/10 high power field, surgical margins were approached by the tumor at the lateral and deep margins.

The patient was discharged on the tenth postoperative day in a good condition with no wound complications; no recurrence was found 4 months after operation. The study protocols were approved by the Chiang Mai University Institutional Ethical Committee, Thailand and informed written patient consent was also obtained.

\section{Discussion}

Phyllodes tumors are rare especially those that rupture. From the literature review, few studies were found in the database with each study reporting only one case. ${ }^{4-6}$ These tumors usually are presented as a well-circumscribed, firm, and mobile mass or nodule characterized by rapid growth over a short time period and classified as benign, intermediate, or malignant tumor. ${ }^{7}$ Mammography and ultrasound images were difficult to distinguish between fibroadenoma and phyllodes tumors. ${ }^{8}$ The histopathology

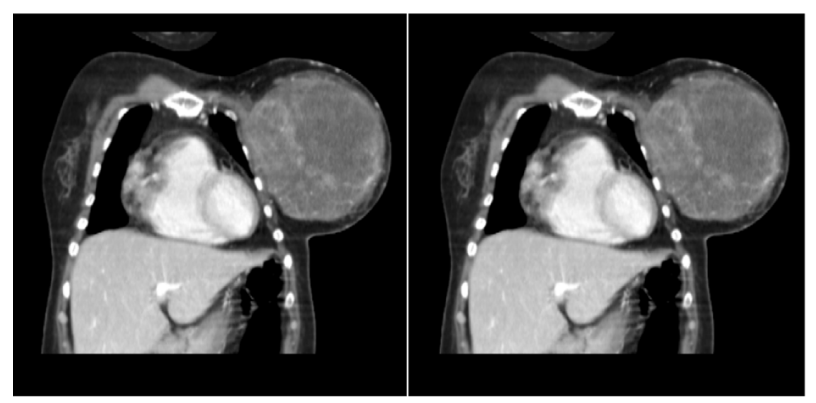

Figure 2 CT chest shows huge inhomogeneous enhanced mass at left breast. Abbreviation: CT, computed tomography.

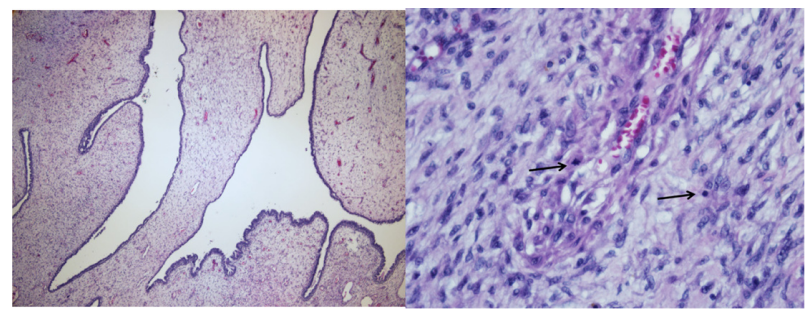

Figure 3 Microscopic study of phyllodes tumor.

Notes: Microscopic study of phyllodes tumor displays increased stromal cells with cleft- and leaf-like appearance of ducts and malignant spindle cells in the stroma with frequent mitoses (arrows) $(\mathrm{H} \& \mathrm{E} \times 40)$.

Abbreviation: $\mathrm{H} \& \mathrm{E}$, hematoxylin and eosin.

of phyllodes tumors is characterized by epithelial-lined cleft-like spaces with a hypercellular stroma, organized into leaf-like fronds. Standard treatment for phyllodes tumor is surgery and the treatment of choice is wide local excision $^{9}$ with adequate margin of healthy tissue (greater than $1.0 \mathrm{~cm}$ ), but mastectomy is recommended for high tumor-to-breast ratios or when an inability to obtain adequate margins occurs. Adjuvant chemotherapy including doxorubicin and dacarbazine is rarely used for this type of breast tumor; few studies have reported that this treatment did not affect patients' survival. ${ }^{10,11}$ Adjuvant radiotherapy is also controversial. Some studies have shown no improvement in the prognosis, whereas other studies have shown better local control ${ }^{12}$ but did not affect disease free survival or overall survival. ${ }^{13}$ Chaney et al suggested that radiotherapy is recommended for borderline or malignant phyllodes tumors because the risk of local recurrence is high especially with positive margins, margin less than 0.5 $\mathrm{cm}$, tumor size greater than $10 \mathrm{~cm}$, or recurrent disease. ${ }^{10}$ Most phyllodes tumor express ER and PR and endocrine therapy has no proven role in the adjuvant treatment, and ER and PR decrease expression in high-grade subgroup of phyllodes tumor. ${ }^{14}$

Table I Literature data of patients with ruptured phyllodes tumor $4,6,15,16$

\begin{tabular}{|c|c|c|c|c|}
\hline $\begin{array}{l}\text { Patient } \\
\text { no }\end{array}$ & $\begin{array}{l}\text { Age } \\
\text { (years) }\end{array}$ & Operation & Country & $\begin{array}{l}\text { Follow- } \\
\text { up after } \\
\text { operation }\end{array}$ \\
\hline I & 32 & Wide local excision & Bangladesh & $\begin{array}{l}9 \text { months; } \\
\text { no recurrence }\end{array}$ \\
\hline 2 & 40 & Simple mastectomy & India & $\begin{array}{l}3 \text { years; } \\
\text { no recurrence }\end{array}$ \\
\hline 3 & 38 & Simple mastectomy & Pakistan & $\begin{array}{l}\text { I year; } \\
\text { no recurrence }\end{array}$ \\
\hline 4 & 48 & Simple mastectomy & Sri Lanka & $\begin{array}{l}4 \text { years; } \\
\text { no recurrence }\end{array}$ \\
\hline
\end{tabular}


We have reviewed the ruptured phyllodes tumor of the breast and its summary is given in Table 1.

\section{Conclusion}

Phyllodes tumors are uncommon fibroepithelial breast tumors in which ruptures are extremely rare. There is a high index of suspicion for this tumor if a patient has a history of rapid-growth of breast mass. Phyllodes tumors often appear on ultrasound and mammography and are difficult to distinguish from fibroadenoma. A simple mastectomy is performed only if negative margins cannot be obtained by wide local excision. Inadequate surgical management may lead to local recurrence. Adjuvant radiotherapy is considered in individual patients.

\section{Disclosure}

The authors report no conflicts of interest in this work.

\section{References}

1. Guerrero MA, Ballard BR, Grau AM. Malignant phyllodes tumor of the breast: review of the literature and case report of stromal overgrowth. Surg Oncol. 2003;12(1):27-37.

2. Spitaleri G, Toesca A, Botteri E, et al. Breast phyllodes tumor: a review of literature and a single center retrospective series analysis. Crit Rev Oncol Hematol. 2013;88(2):427-436.

3. Macdonald OK, Lee CM, Tward JD, Chappel CD, Gaffney DK. Malignant phyllodes tumor of the female breast. Cancer. 2006;107(9): 2127-2133.

4. Nabi J, Akhter SM, Authoy FN. A case of large phyllodes tumor causing "rupture" of the breast: a unique presentation. Case Rep Oncol Med. 2013;2013:871292.
5. Walravens C, De Greef C. Giant phyllodes tumour of the breast. J Plast Reconstr Aesthet Surg. 2008;61(10):e9-e11.

6. Wijeyaratne SM. Breast "rupture" due to a phyllodes tumour. BMJ Case Rep. 2010;2010.

7. Grenier J, Delbaldo C, Zelek L, Piedbois P. Tumeurs phyllodes et sarcomes du sein: mise au point [Phyllodes tumors and breast sarcomas: a review]. Bull Cancer. 2010;97(10):1197-1207.

8. Guerrero MA, Ballard BR, Grau AM. Malignant phyllodes tumor of the breast: review of the literature and case report of stromal overgrowth. Surg Oncol. 2003;12(1):27-37.

9. Roberts N, Runk DM. Aggressive malignant phyllodes tumor. Int $J$ Surg Case Rep. 2015;8C:161-165.

10. Chaney AW, Pollack A, McNeese MD, Zagars GK. Adjuvant radiotherapy for phyllodes tumor of breast. Radiat Oncol Investig. 1998;6(6):264-267.

11. Morales-Vásquez F, Gonzalez-Angulo AM, Broglio K, et al. Adjuvant chemotherapy with doxorubicin and dacarbazine has no effect in recurrence-free survival of malignant phyllodes tumors of the breast. Breast J. 2007;13(6):551-556.

12. Pandey M, Mathew A, Kattoor J, et al. Malignant phyllodes tumor. Breast J. 2001;7(6):411-416.

13. Gnerlich JL, Williams RT, Yao K, Jaskowiak N, Kulkarni SA. Utilization of radiotherapy for malignant phyllodes tumors: analysis of the National Cancer Data Base, 1998-2009. Ann Surg Oncol. 2014;21(4):1222-1230.

14. Tse GMK, Lee CS, Kung FYL, et al. Hormonal receptors expression in epithelial cells of mammary phyllodes tumors correlates with pathologic grade of the tumor: a multicenter study of 143 cases. Am J Clin Pathol. 2002;118(4):522-526.

15. Jaka RC, Kumar KM, Gopinath KS. Spontaneous expulsion of benign phyllodes. Breast J. 2009;15(3):309.

16. Saeed S, Ali A, Memon AS. Giant malignant phyllodes tumor at a tertiary care hospital of Karachi, Pakistan. J Pioneer Med Sci. 2014;4(3):143-145.
International Medical Case Reports Journal

\section{Publish your work in this journal}

The International Medical Case Reports Journal is an international, peer-reviewed open-access journal publishing original case reports from all medical specialties. Previously unpublished medical posters are also accepted relating to any area of clinical or preclinical science. Submissions should not normally exceed 2,000 words or

\section{Dovepress}

4 published pages including figures, diagrams and references. The manuscript management system is completely online and includes a very quick and fair peer-review system, which is all easy to use. Visit http://www.dovepress.com/testimonials.php to read real quotes from published authors. 